\title{
Dentinal Microcracks after Root Canal Instrumentation Using Instruments Manufactured with Different NiTi Alloys and the SAF System: A Systematic Review
}

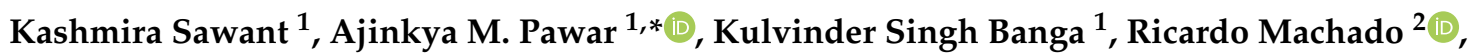 \\ Mohmed Isaqali Karobari ${ }^{3,4}\left(\mathbb{D}\right.$, Anand Marya ${ }^{5}\left(\mathbb{C}\right.$, Pietro Messina ${ }^{6}$ and Giuseppe Alessandro Scardina ${ }^{6, *(1)}$ \\ 1 Department of Conservative Dentistry and Endodontics, Nair Hospital Dental College, \\ Mumbai 400034, Maharashtra, India; kashmiraswnt@gmail.com (K.S.); ksbanga@gmail.com (K.S.B.) \\ 2 Clinical Practice Limited to Endodontics, Navegantes 88370-100, Santa Catarina, Brazil; \\ ricardo.machado.endo@gmail.com \\ 3 Conservative Dentistry Unit, School of Dental Sciences, Universiti Sains Malaysia, Health Campus, \\ Kubang Kerian, Kota Bharu 16150, Kelantan, Malaysia; dr.isaq@gmail.com \\ 4 Department of Conservative Dentistry \& Endodontics, Saveetha Dental College \& Hospitals, \\ Saveetha Institute of Medical and Technical Sciences University, Chennai 600077, Tamil Nadu, India \\ 5 Department of Orthodontics, University of Puthisastra, Phnom Penh 55 180, Cambodia; \\ amarya@puthisastra.edu.kh \\ 6 Department of Surgical, Oncological and Stomatological Disciplines, University of Palermo, \\ 90133 Palermo, Italy; pietro.messina01@unipa.it \\ * Correspondence: ajinkya@drpawars.com (A.M.P.); alessandro.scardina@unipa.it (G.A.S.)
}

Citation: Sawant, K.; Pawar, A.M.; Banga, K.S.; Machado, R.; Karobari, M.I.; Marya, A.; Messina, P.; Scardina, G.A. Dentinal Microcracks after Root Canal Instrumentation Using Instruments Manufactured with Different NiTi Alloys and the SAF System: A Systematic Review. Appl. Sci. 2021, 11, 4984. https://doi.org/ 10.3390/app11114984

Academic Editor:

Gianluca Gambarini

Received: 30 April 2021

Accepted: 26 May 2021

Published: 28 May 2021

Publisher's Note: MDPI stays neutral with regard to jurisdictional claims in published maps and institutional affiliations.

Copyright: (c) 2021 by the authors. Licensee MDPI, Basel, Switzerland. This article is an open access article distributed under the terms and conditions of the Creative Commons Attribution (CC BY) license (https:// creativecommons.org/licenses/by/ $4.0 /)$.
Abstract: Aim: The aim of this systematic analysis was to assess the prevalence of dentinal microcracks at various levels $(3,6$, and $9 \mathrm{~mm}$ from the apex) after using instruments made with conventional, R-Phase, and M-Wire NiTi alloys and the SAF system. Materials and Methods: Electronic searches were conducted in the databases Embase, Cochrane Library, Scopus, PubMed, and Web of Science. To arrange search methods, "MeSH" terms and/or keywords typically associated with the subject were paired with the Boolean operators "AND" and "OR." Additional searches were conducted on the websites of four separate endodontic journals. After reading the titles and excluding duplicates, 1000 of the 1343 documents originally found were eliminated. Upon reviewing the abstracts, 310 of the remaining 343 experiments were also eliminated. Based on qualifying requirements, only 13 of the remaining 33 articles were included in the qualitative review. Results: All systems triggered dentinal microcracks; however, when chemo-mechanical preparation was performed using Self-Adjusting File (SAF) and systems manufactured with R-phase technology-K3XF and Twisted File Adaptive (TFA) - less of these defects were found when compared to those manufactured with traditional NiTi-ProTaper Universal and Mtwo-and with M-Wire-ProTaper Next, Reciproc, and WaveOne. Conclusions: A lower prevalence of dentinal microcracks was observed after using SAF and endodontic systems manufactured with R-phase.

Keywords: NiTi instruments; dentin microcracks; Self-Adjusting File system; martensite-wire; R-phase; ProTaper Universal files; Mtwo files; ProTaper Next files; Reciproc files; WAVEONE files; TF Adaptive files; K3XF files

\section{Introduction}

Endodontic treatment is primarily performed to maintain or reestablish the health of peri-radicular tissues in the vicinity of the involved teeth [1]. In vital teeth, the pulp is removed, and the root canal is cleaned, shaped, and filled with a biocompatible material. Since the periapical tissues are not involved, the procedure is based on a "prophylactic target" to prevent the formation of a peri-radicular lesion [2]. The pulp cells in necrotic teeth are destroyed and permanently compromised, enabling microbial colonization of the root canal system (RCS) [3]. While a periapical lesion is not necessarily visible on 
radiographs, it can be present [4], and treatment is done to control the endodontic infection and avoid or preserve the integrity of the peri-radicular tissues [5].

The key step in removing the pulp or controlling the endodontic infection is biomechanical preparation [6]. It is performed by operating endodontic instruments and irrigating solutions confined within the radicular space [7]. While the cleaning and shaping processes occur concurrently and thus didactically [8], it is crucial to consider the whole process as it occurs in stages. Endodontic files are mostly responsible for shaping and mechanical cleaning of the root canal, while irrigating solutions have a chemical effect on root canals' contents [3].

Stainless steel hand files were traditionally used to shape the root canal. Due to its metallurgical characteristics, the occurrence of errors and injuries was high [9]. In the late 1980s, the invention of nickel-titanium (NiTi) alloys culminated in a breakthrough in endodontics. These files have significant advantages over stainless steel files, especially in terms of instrumentation safety [10]. The existence of a fixed taper and radial lands along the length of the active section distinguished the first generation of these instruments. The first generation NiTi rotary files included Lightspeed (Lightspeed Endodontics-1992), Profile (Dentsply Tulsa-1993), Quantec (Sybron Endo-1996), and GT System (Dentsply Tulsa-1998) [11-13].

Conventional NiTi endodontic instruments contain approximately $56 \%$ nickel and $44 \%$ titanium. The finish temperature of austenite is lower than body temperature. As a result, these instruments are mostly composed of the austenite phase and exhibit super elastic properties. Traditional NiTi endodontic instruments, on the other hand, are made using a machining procedure, which can result in surface defects. These flaws are to blame for negative effects on fracture resistance, cutting performance, and corrosion resistance of the files [14].

In 2007, Sportswire LLC (Langley, OK, USA) developed a patented thermomechanical manufacturing established with the aim of producing a more flexible NiTi alloy with improved cyclic fatigue resistance. The new NiTi alloy is known as M-Wire [15]. The starting content for M-Wire thermal processing was a Nitinol formulation containing approximately $55.8 \pm 1.5 \%$ nickel, $44.2 \pm 1.5 \%$ titanium, and less than $1 \%$ trace elements [16]. Several papers have shown that M-Wire is more flexible than conventionally-treated NiTi alloys [17-19]. ProTaper Next (Dentsply-Maillefer), WaveOne (Dentsply-Maillefer), and Reciproc (VDW) are examples of systems manufactured by M-Wire.

Shortly after the launch of M-Wire in 2008, SybronEndo (Orange, CA, USA) created another manufacturing method to produce Twisted File, a revolutionary rotary NiTi system (TF). Three new technologies were used in the production of TF: R-phase heat treatment, metal wire spinning, and a special surface treatment [20]. The twisting method is carried out by converting a raw NiTi wire in an austenitic state into R-phase using a patented thermal process. R-phase has a lower shear modulus and a transition strain that is one-tenth that of martensite transformation [21]. As a result, less stress is required to induce plastic deformation in R-phase, allowing the twisting mechanism to occur. To retain its new shape [22], TF is transformed back to austenite through additional thermal procedures after twisting. K3XF and TF Adaptive are two other systems that use R-phase technology (TFA, SybronEndo, Orange, CA, USA). Unlike the instruments of the TF and TFA systems, K3XF files are created using conventional grinding processes and R-phase heat treatment after the fact. TFA instruments are used with a new adaptive motion technology that allows for either rotary or reciprocating file kinematics based on the strain exerted by the root canal walls [14].

The Self-Adjusting File system (SAF; ReDent-Nova, Ra'anana, Israel) differs from other systems for two key reasons. First, the SAF is a hollow and adjustable file that adheres to the outline of the root canal in three dimensions, with the ability to fit to its cross-section. The SAF vibrates and eliminates a uniform dentin layer from the canal walls, also in oval, flat oval, and in any irregularly-shaped root canal while in use. Rather than machining a central part of the root canal into a circular cross-section, the SAF causes a flat canal to remain flat with slightly wider dimensions. Second, the hollow file allows for continual 
irrigation of the root canal during the process, with the irrigant being activated further by the vibrating motion of the file, which induces turbulence in the root canal. Irrigation is delivered by a special rinsing unit that delivers the irrigant at a flow rate of $5 \mathrm{~mL} / \mathrm{min}$ (VATEA, ReDent-Nova) [23,24].

The advancement of NiTi instruments has made endodontic care even more convenient for both patients and practitioners. However, clinicians and experts continue to be concerned with root canal anomalies $[25,26]$, radicular perforations $[25,26]$, instrument fracture $[25,26]$, and dentinal microcracks.

Dentinal microcracks are complete or incomplete thickness cracks that occur on the root canal walls as a result of endodontic file operation. These defects result in vertical root fracture [27] and tooth extraction [28-30]. Regardless of the NiTi file system used during chemo-mechanical preparation, dentinal microcracks have been observed.

The goal of the study is to analyze the effect of different file systems with respect to their different composition of NiTi alloys and cross-sectional shapes in dentinal crack formation during root canal instrumentation.

\section{Materials and Methods}

\subsection{Protocol and Registration}

The current study adhered to the Preferred Reporting Items for Systematic Review and Meta-Analysis-PRISMA (http:/ / www.prisma-statement.org) guidelines. It was accessed on 9 August 2020. However, since no clinical records were included, it was not registered in PROSPERO (International Prospective Registry of Systematic Reviews).

\subsection{Research Question}

Centered on the "PICOS" (PRISMA-P 2016) technique, studies that compared the occurrence of dentinal microcracks resultant from endodontic files made with different NiTi alloy composition and cross-sectional geometry were included:

- $\quad$ P (population): extracted human teeth with complete rhizogenesis;

- I (intervention): biomechanical preparation;

- $\quad$ C (comparison): endodontic files made by different NiTi alloys;

- $\quad \mathrm{O}$ (result): dentinal microcrack formation.

- $\quad$ S (study design): laboratory studies.

\subsection{Search Strategies}

Refer to Table 1.

Table 1. Sources of information and search strategies.

\begin{tabular}{|c|c|c|}
\hline Databases & Search Strategies & Results \\
\hline PubMed & $\begin{array}{l}\text { (“Endodontics" OR “endodontics" OR “endodontic treatment" OR “Root canal } \\
\text { instrumentation" OR “NiTi file system" OR “Rotary instruments" OR } \\
\text { "Reciprocating file system") AND (“Dentinal cracks" OR “Dentin defect”) }\end{array}$ & 510 \\
\hline Embase & $\begin{array}{l}\text { (“Endodontics" OR “endodontics" OR “endodontic treatment" OR “Root canal } \\
\text { instrumentation" OR “NiTi file system" OR “Rotary instruments” OR } \\
\text { “Reciprocating file system") AND ("Dentinal cracks" OR “Dentin defect") }\end{array}$ & 354 \\
\hline Web of Science & $\begin{array}{c}\text { ("Endodontics" OR “Endodontic Treatment" OR “Root canal instrumentation" OR } \\
\text { "NiTi file systems" OR “Rotary instruments" OR "Reciprocating file systems") } \\
\text { AND (“Dentinal cracks" OR “Dentin defect") }\end{array}$ & 234 \\
\hline Scopus & $\begin{array}{l}\text { (“Endodontics" OR “endodontics" OR “endodontic treatment” OR “Root canal } \\
\text { instrumentation" OR “NiTi file system" OR “Rotary instruments" OR } \\
\text { "Reciprocating file system") AND (“Dentinal cracks" OR “Dentin defect”) }\end{array}$ & 222 \\
\hline Hand search & $\begin{array}{l}\text { Australian Endodontic Journal, Iranian Endodontic Journal, International Endodontic } \\
\text { Journal, and Journal of Endodontics }\end{array}$ & 23 \\
\hline Total & & 1343 \\
\hline
\end{tabular}




\subsection{Data Sources}

Two independent researchers (K.S. and A.P.) conducted an electronic literature search up to 10 August 2019, using MeSH terms and keywords together with the Boolean operators "OR" and "AND" to collect the relevant literature using suitable filters. The keywords "NiTi file systems", "rotary instruments", "reciprocating file systems", "dentin microcracks", "dentinal defects", "dentinal craze lines" and "endodontics" were combined with the Boolean operators "OR" and "AND" to gather the required literature using appropriate filters. The complete search strategy with the number of articles resulted from them is presented in Table 1.

\subsection{Eligibility Criteria}

A search of the literature was conducted to find in vitro studies that examined the occurrence of dentinal defects after using instruments made with conventional, R-Phase, and M-Wire NiTi alloys and SAF systems, and were published between 1 January 2012, and 10 August 2019. Based on the PICOS approach, two reviewers reviewed the full texts of the remaining papers and defined inclusion and exclusion requirements. Disputes were resolved by the decision of a third reviewer. Table 2 shows the inclusion and removal conditions.

Table 2. Inclusion and exclusion criteria adopted.

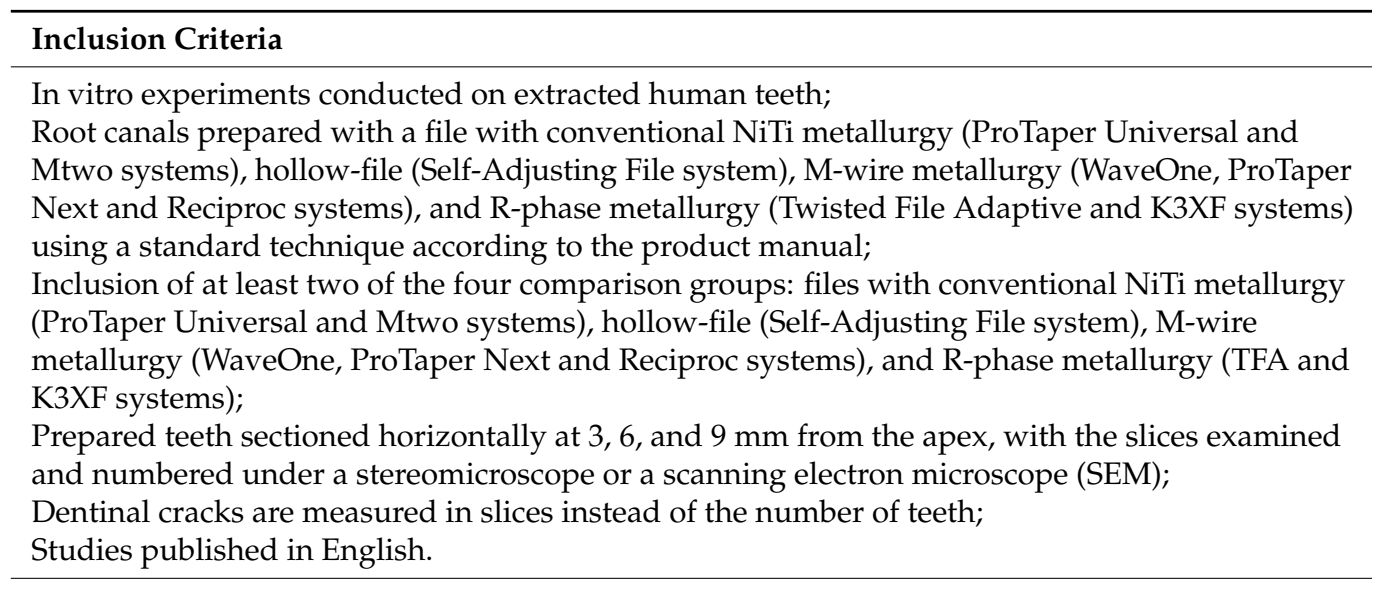

\section{Exclusion Criteria}

In vivo studies or studies not of human teeth;

Root canals prepared with instruments other than files with conventional NiTi metallurgy

(ProTaper Universal and Mtwo systems), hollow-file (Self-Adjusting File system) and M-wire metallurgy (WaveOne, ProTaper Next and Reciproc systems);

Evaluation of the crack initiation at levels other than 3,6, and $9 \mathrm{~mm}$ from the apex;

Studies without a control group;

Evaluation of dentinal cracks after the root canal filling procedure;

Retreatment;

Unavailable data.

Note: If any lines, microcracks, or fractures were detected in the dentinal slice, it was defined as a "slice with cracks". A dentinal slice devoid of any craze lines, microcracks, or fractures on the external surface of the root or the internal surface of the root canal wall was defined as a "slice without cracks".

\subsection{Study Selection}

Two reviewers (K.S. and A.P.) were in charge of selecting/excluding publications based on a linear review of names, abstracts, and full texts (in cases of doubt). Based on the qualifying criterion, the remaining articles were read in their entirety before making the final decision (Table 2). This whole method was carried out separately, with the assistance of a third researcher (R.M.) in the cases of questions or disputes. 


\subsection{Data Extraction}

After reading the full text, two researchers (K.S and A.P.) conducted independent sampling and data extraction to collect data from qualifying studies. Significant information was extracted and reported from the included research, including the first author, publication year, region, probability of bias, reference group, root curvature, number of tooth slices per group, identification of microcracks prior to the sample, file system used, tool used to classify dentinal microcracks, control group, and irrigant method. Owing to the methodological heterogeneity of the findings, a meta-analysis was not conducted.

\subsection{Quality Assessment}

Two researchers (K.S. and A.P.) independently assessed the possibility of prejudice in the included experiments using the Joanna Briggs' consistency evaluation of in vitro studies [31]. A third researcher (R.M.) was consulted if there were any contradictions.

The assessment tool includes the following domains:

1. Congruity between the stated philosophical perspective and the research methodology.

2. Congruity between the research methodology and research question or objectives.

3. Congruity between the research methodology and the method used to collect data.

4. Congruity between the research methodology and representation, and analysis of data.

5. Congruity between the research methodology and interpretation of results.

6. Statement locating the researcher culturally or theoretically.

7. Influence of researcher on the research and vice versa addressed.

8. Representation of participants and their voices.

9. Assessment of research ethicality according to the current criteria for recent studies and if there is evidence of ethical approval by an appropriate body.

10. Assess whether the conclusion drawn in the project report flow from the analysis or interpretation of data.

Each area was assigned a Yes, No, Uncertain, or Not Available rating. According to Joanna Briggs' quality evaluation guidelines, these tests were recorded for each chosen sample. Each analysis was then classified as either an inclusion, exclusion, or obtain further detail for the systematic review.

\section{Results}

\subsection{Study Selection Results}

The PRISMA flowchart in Figure 1 shows the results of the literature scan. Initial electronic and manual searches yielded 1343 results. After reading the titles and excluding duplicates, 1000 of the 1343 documents originally found were eliminated. Since reviewing the abstracts, 310 of the remaining 343 experiments were also eliminated. Based on the qualifying criterion (Table 2), just 13 of the remaining 33 articles were included in the qualitative study. 

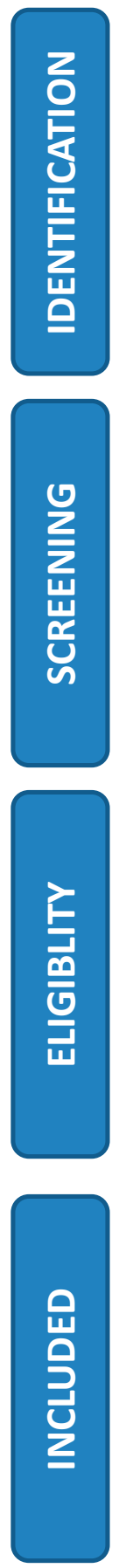

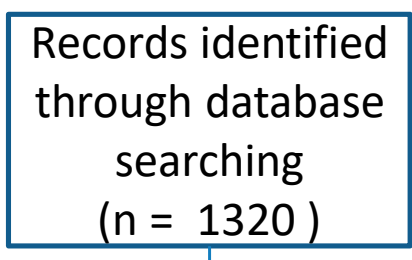

Records identified though hand searching $(n=23)$
Records after duplicates removed $(n=343)$

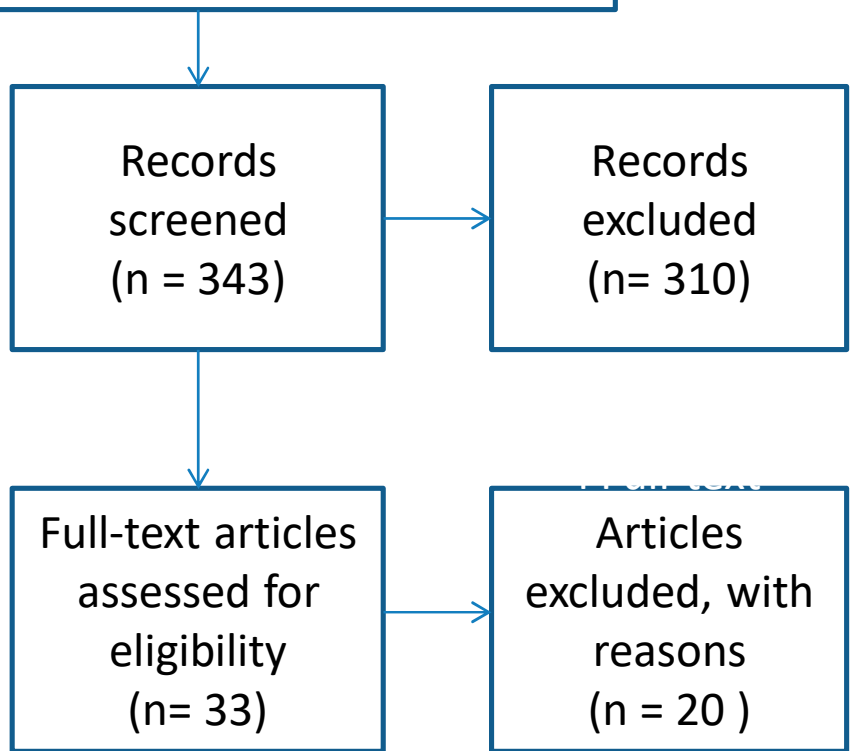

Figure 1. Flowchart on number of articles selected in the systematic review based on eligibility criteria.

\subsection{Study Features}

Table 3 summarizes the characteristics of the 13 experiments chosen for quantitative analysis. All of the experiments used comparative research classes. In total, 1529 samples of mandibular teeth (incisors, premolars, and molars) were analyzed. The root curvatures ranged from 0 to 40 degrees. Prior to instrumentation, all of the teeth were scanned with a SEM or a stereomicroscope to detect prior dentinal microcracks. After the instrumentation, the same was done. A placebo group of unprepared teeth was included in both trials. In both experiments, irrigant solutions were used to prepare the root canals. In all studies, the occurrence of dentinal microcracks was assessed in slices taken from the apex at 3,6, and $9 \mathrm{~mm}$. Out of the 13 studies [32-44], 11 used devices made with conventional NiTi alloy [32-38,41-44], 2 used SAF [32,44], 13 used M-wire [32-44], and 5 used R-phase [36,38-41]. 
Table 3. Articles included in the systematic review.

\begin{tabular}{|c|c|c|c|c|c|c|c|c|c|c|c|}
\hline \multirow[t]{2}{*}{ No. } & \multirow[t]{2}{*}{ Article Title } & \multicolumn{2}{|c|}{$\begin{array}{l}\text { Conventional } \\
\text { NiTi }\end{array}$} & \multirow{2}{*}{$\begin{array}{c}\begin{array}{c}\text { Hollow- } \\
\text { File } \\
\text { System }\end{array} \\
\text { SAF } \\
\end{array}$} & \multicolumn{3}{|c|}{ M-Wire } & \multicolumn{2}{|c|}{ R-Phase } & \multirow[t]{2}{*}{$\begin{array}{c}\text { Section } \\
3,6,9 \mathrm{~mm}\end{array}$} & \multirow[t]{2}{*}{ Technique } \\
\hline & & PTU & Mtwo & & PTN & RC & WO & TFA & K3XF & & \\
\hline 1 & $\begin{array}{c}\text { In Vitro Comparative } \\
\text { Evaluation of Dentinal } \\
\text { Microcracks' Formation } \\
\text { during Root Canal } \\
\text { Preparation by Different } \\
\text { Nickel-Titanium File Systems } \\
\text { [32]. }\end{array}$ & Yes & & Yes & Yes & & Yes & & & Yes & $\begin{array}{l}\text { Stereomicro- } \\
\text { scope }\end{array}$ \\
\hline 2 & $\begin{array}{c}\text { Effect of Root Canal } \\
\text { Preparation Techniques on } \\
\text { Crack Formation in Root } \\
\text { Dentin [33]. }\end{array}$ & Yes & & & & & Yes & & & Yes & $\begin{array}{l}\text { Stereomicro- } \\
\text { scope }\end{array}$ \\
\hline 3 & $\begin{array}{l}\text { Incidence of Dentinal Defects } \\
\text { after Root Canal Preparation } \\
\text { Reciprocating versus Rotary } \\
\text { Instrumentation [34]. }\end{array}$ & Yes & & & & Yes & Yes & & & Yes & $\begin{array}{l}\text { Stereomicro- } \\
\text { scope }\end{array}$ \\
\hline 4 & $\begin{array}{l}\text { Assessment of Dentinal } \\
\text { Damage during Canal } \\
\text { Preparation Using } \\
\text { Reciprocating and Rotary } \\
\text { Files [35]. }\end{array}$ & Yes & & & & & Yes & & & Yes & $\begin{array}{l}\text { Stereomicro- } \\
\text { scope }\end{array}$ \\
\hline 5 & $\begin{array}{l}\text { Dentinal Crack Formation } \\
\text { during Root Canal } \\
\text { Preparations by the Twisted } \\
\text { File Adaptive, ProTaper Next, } \\
\text { ProTaper Universal and } \\
\text { WaveOne Instruments [36]. }\end{array}$ & Yes & & & Yes & & Yes & Yes & & Yes & $\begin{array}{l}\text { Stereomicro- } \\
\text { scope }\end{array}$ \\
\hline 6 & $\begin{array}{l}\text { The Effects of Different } \\
\text { Nickel-Titanium Instruments } \\
\text { on Dentinal Microcrack } \\
\text { Formations during Root } \\
\text { Canal Preparation [37]. }\end{array}$ & Yes & & & Yes & Yes & & & & Yes & $\begin{array}{l}\text { Stereomicro- } \\
\text { scope }\end{array}$ \\
\hline 7 & $\begin{array}{c}\text { Comparison of Incidence of } \\
\text { Dentinal Defects after Root } \\
\text { Canal Preparation with } \\
\text { Continuous Rotation and } \\
\text { Reciprocating } \\
\text { Instrumentation [38]. }\end{array}$ & Yes & & & & & Yes & & Yes & Yes & $\begin{array}{l}\text { Stereomicro- } \\
\text { scope }\end{array}$ \\
\hline 8 & $\begin{array}{c}\text { Evaluation of Dentinal } \\
\text { Defects during Root Canal } \\
\text { Preparation Using } \\
\text { Thermomechanically- } \\
\text { Processed Nickel-Titanium } \\
\text { Files [39]. }\end{array}$ & & & & Yes & Yes & & Yes & Yes & Yes & $\begin{array}{l}\text { Stereomicro- } \\
\text { scope }\end{array}$ \\
\hline 9 & $\begin{array}{l}\text { To Compare the Incidence of } \\
\text { Dentinal Cracks after } \\
\text { Instrumentation with Rotary, } \\
\text { Reciprocating Twisted File } \\
\text { Adaptive System [40]. }\end{array}$ & & & & Yes & Yes & & Yes & & Yes & $\begin{array}{l}\text { Stereomicro- } \\
\text { scope }\end{array}$ \\
\hline 10 & $\begin{array}{l}\text { Comparison of Dentinal and } \\
\text { Apical Crack Formation } \\
\text { Caused by Four Different } \\
\text { Nickel-Titanium Rotary and } \\
\text { Reciprocating Systems in } \\
\text { Large and Small Canals [41]. }\end{array}$ & Yes & & & & & Yes & Yes & & Yes & SEM \\
\hline
\end{tabular}


Table 3. Cont.

\begin{tabular}{|c|c|c|c|c|c|c|c|c|c|c|c|}
\hline \multirow[t]{2}{*}{ No. } & \multirow[t]{2}{*}{ Article Title } & \multicolumn{2}{|c|}{$\begin{array}{l}\text { Conventional } \\
\text { NiTi }\end{array}$} & \multirow{2}{*}{$\begin{array}{c}\begin{array}{c}\text { Hollow- } \\
\text { File } \\
\text { System }\end{array} \\
\text { SAF } \\
\end{array}$} & \multicolumn{3}{|c|}{ M-Wire } & \multicolumn{2}{|c|}{ R-Phase } & \multirow[t]{2}{*}{$\begin{array}{c}\text { Section } \\
3,6,9 \mathrm{~mm}\end{array}$} & \multirow[t]{2}{*}{ Technique } \\
\hline & & PTU & Mtwo & & PTN & RC & WO & TFA & $\mathrm{K} 3 \mathrm{XF}$ & & \\
\hline 11 & $\begin{array}{l}\text { Effect of Reciprocating File } \\
\text { Motion on Microcrack } \\
\text { Formation in Root Canals: an } \\
\text { SEM Study [42]. }\end{array}$ & Yes & & & & & Yes & & & Yes & SEM \\
\hline 12 & $\begin{array}{c}\text { Incidence of Dentinal Cracks } \\
\text { after Root Canal } \\
\text { Preparation with ProTaper } \\
\text { Gold, Profile Vortex, } \\
\text { F360, Reciproc and ProTaper } \\
\text { [43]. }\end{array}$ & Yes & & & & & Yes & & & Yes & $\begin{array}{l}\text { Stereomicro- } \\
\text { scope }\end{array}$ \\
\hline 13 & $\begin{array}{l}\text { Evaluation of the Incidence of } \\
\text { Microcracks caused by Mtwo } \\
\text { and ProTaper Next Rotary } \\
\text { File Systems versus the } \\
\text { Self-Adjusting File: A } \\
\text { Scanning Electron } \\
\text { Microscopic Study [44]. }\end{array}$ & & Yes & Yes & Yes & & & & & Yes & SEM \\
\hline
\end{tabular}

\subsection{Quality Assessment}

All papers related to the current study were shortlisted and screened based on names, abstracts, and finally, the entire articles were read one by one and reviewed for quality evaluation using the Joanna Briggs' quality assessment of in vitro studies' guidelines. In all, 343 papers were searched, with 330 articles being omitted for reasons such as lack of clarification of the process, research nature and results, consistency problems, and data completeness. Articles that lacked congruence between the research approach and the research query or purpose, the procedure used to gather data, data representation and analysis, and outcome interpretation were omitted (Table 4). Since the total number of experiments used in each study was limited, no statistical assessment of publishing bias (Trimand-fill, Egger's test) was carried out. Similarly, due to the scarcity of available evidence, no susceptibility or subgroup studies were carried out. 
Table 4. Characteristics of the studies included in the systematic review.

\begin{tabular}{|c|c|c|c|c|c|c|c|c|c|c|c|c|c|c|c|}
\hline No. & Title & Authors & Journal & Country & Year & Teeth & No. of Samples & $\begin{array}{l}\text { Pre Instrumen- } \\
\text { tation } \\
\text { Evaluation for } \\
\text { Cracks }\end{array}$ & Root Curvature & Control Group & File Group & $\begin{array}{l}\text { Sectioning } 3 \\
\mathrm{~mm}, 6 \mathrm{~mm}, 9 \\
\mathrm{~mm}\end{array}$ & $\begin{array}{l}\text { Examination } \\
\text { Method }\end{array}$ & $\begin{array}{l}\text { Methodology Is } \\
\text { Well Described }\end{array}$ & Irrigant \\
\hline 1. & $\begin{array}{l}\text { In Vitro Comparative } \\
\text { Evaluation of Dentinal } \\
\text { Microcracks' Formation } \\
\text { during Root Canal } \\
\text { Preparation by Different } \\
\text { Nickel-Titanium Difterestems } \\
\text { [32]]. }\end{array}$ & $\begin{array}{l}\text { Akshayraj K. Langaliya, } \\
\text { Anjali K. Kothari, } \\
\text { Nishantkumar R. Surti, } \\
\text { Ambiben R. P.atel, Prerak R. } \\
\text { Doshil, and Devarshi J. } \\
\text { Pandya }\end{array}$ & $\begin{array}{l}\text { Saudi En- } \\
\text { dodontic } \\
\text { Journal }\end{array}$ & India & 2018 & $\begin{array}{c}\text { Mandibular } \\
\text { premolars }\end{array}$ & 84 & Yes & Straight & Unprepared & $\begin{array}{l}\text { ProTaper } \\
\text { Universal, } \\
\text { ProTaper Next } \\
\text { and WaveOne } \\
\text { and SAF }\end{array}$ & Yes & $\begin{array}{l}\text { Stereomicro- } \\
\text { scope }\end{array}$ & Yes & Yes \\
\hline 2. & $\begin{array}{l}\text { Effect of Root Canal } \\
\text { Preparation Techniques on } \\
\text { Crack Formation in Root } \\
\text { Dentin [33]. }\end{array}$ & 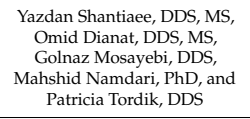 & PubMed & Iran & 2018 & $\begin{array}{l}\text { Mandibular 15t } \\
\text { premolars }\end{array}$ & 150 & Yes & Curvature $<25^{\circ}$ & Unprepared & $\begin{array}{l}\text { ProTaper } \\
\text { Universal and } \\
\text { WaveOne }\end{array}$ & Yes & $\begin{array}{l}\text { Stereomicro- } \\
\text { scope }\end{array}$ & Yes & Yes \\
\hline 3. & $\begin{array}{l}\text { Incidence of Dentinal Defects } \\
\text { after Root Canal Preparation } \\
\text { Reciprocating versus Rotary } \\
\text { Instrumentation [34]. }\end{array}$ & Bürklein, Tsotsis, and Schäfer & PubMed & Germany & 2012 & $\begin{array}{c}\text { Mandibular central } \\
\text { incisors }\end{array}$ & 100 & Yes & $\begin{array}{l}\text { Straight } \\
\left(<5^{\circ}\right)\end{array}$ & Unprepared & $\begin{array}{c}\text { ProTaper } \\
\text { Universal, } \\
\text { Reciproc and } \\
\text { WaveOne }\end{array}$ & Yes & Stereomicroscope & Yes & Yes \\
\hline 4. & $\begin{array}{l}\text { Assessment of Dentinal } \\
\text { Damage during Canal } \\
\text { Preparation Using } \\
\text { Reciprocating and Rotary } \\
\text { Files [35]. }\end{array}$ & $\begin{array}{l}\text { Rohit Kansal, Akhil Rajput, } \\
\text { Sangeeta Talwar, and } \\
\text { Ruchika Rooongta }\end{array}$ & PubMed & India & 2015 & $\begin{array}{c}\text { Mandibular } \\
\text { premolars }\end{array}$ & 120 & Yes & Straight & Unprepared & $\begin{array}{l}\text { ProTaper } \\
\text { Universal and } \\
\text { WaveOne }\end{array}$ & Yes & Stereomicroscope & Yes & Yes \\
\hline 5. & 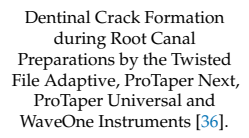 & $\begin{array}{l}\text { Karatas, Krirc, Arslan, } \\
\text { Topṣu, and Yeter }\end{array}$ & PubMed & Turkey & 2015 & $\begin{array}{c}\text { Mandibular central } \\
\text { incisors }\end{array}$ & 75 & Yes & $\begin{array}{l}\text { Straight } \\
\left(<5^{\circ}\right)\end{array}$ & Unprepared & $\begin{array}{c}\text { ProTaper } \\
\text { Universal, } \\
\text { Protaper Next, } \\
\text { WaveOne and } \\
\text { Twisted File } \\
\text { Adaptive }\end{array}$ & Yes & Stereomicroscope & Yes & Yes \\
\hline 7. & $\begin{array}{l}\text { Comparison of Incidence of } \\
\text { Dentinal Defects after Root } \\
\text { Canal Preparatition with } \\
\text { Continuous Rotation and } \\
\text { Reciprocating } \\
\text { Instrumentation [38]. }\end{array}$ & $\begin{array}{l}\text { Monga, Bajaj, Mahajan, and } \\
\text { Garg }\end{array}$ & PubMed & India & 2015 & $\begin{array}{l}\text { Mandibular } \\
\text { premolars }\end{array}$ & 150 & Yes & Straight & Unprepared & $\begin{array}{c}\text { ProTaper } \\
\text { Universal, Wave } \\
\text { One and K3XF }\end{array}$ & Yes & Stereomicroscope & Yes & Yes \\
\hline 8. & $\begin{array}{l}\text { Evaluation of Dentinal } \\
\text { Defects during Root Canal } \\
\text { Preparation Using } \\
\text { Thermomechanically- } \\
\text { Processed Nickel-Titanium } \\
\text { files [39]. } \\
\end{array}$ & Kesim, Sagsen, and Tugrul & PubMed & Turkey & 2017 & $\begin{array}{c}\text { Mandibular } \\
\text { premolars }\end{array}$ & 150 & Yes & $\underset{\substack{\text { Curvature } \\
\left(<5^{\circ}\right)}}{-}$ & Prepared & $\begin{array}{l}\text { Protaper Next, } \\
\text { Reciproc, and } \\
\text { TFA }\end{array}$ & Yes & Stereomicroscope & Yes & Yes \\
\hline 9. & $\begin{array}{l}\text { To Compare the Incidence of } \\
\text { Dentinal Cracks after } \\
\text { Instrumentation with Rotary, } \\
\text { Reciprocation Twisted File } \\
\text { Adaptive System [40]. }\end{array}$ & Kumari and Vishwas & $\begin{array}{l}\text { Hand } \\
\text { search }\end{array}$ & India & 2014 & $\begin{array}{c}\text { Mandibular } \\
\text { premolars }\end{array}$ & 40 & Yes & Straight & Unprepared & $\begin{array}{l}\text { Protaper Next, } \\
\text { WaveOne and } \\
\text { TFA }\end{array}$ & Yes & Stereomicroscope & Yes & Yes \\
\hline 10. & $\begin{array}{l}\text { Comparison of Dentinal and } \\
\text { Apical Crack Formation } \\
\text { caused by Four Different } \\
\text { Nicke-1itanum Rotary and } \\
\text { Reciprocating Systems in } \\
\text { Large and Small Canals [41]. }\end{array}$ & $\begin{array}{l}\text { Zhou, Jiang, S. Wang, X. } \\
\text { Wang, Zhu, and Zhang }\end{array}$ & PubMed & China & 2015 & $\begin{array}{c}\text { Mandibular } \\
\text { premolars and } \\
\text { molars }\end{array}$ & 180 & Yes & Not specified. & Unprepared & $\begin{array}{l}\text { ProTaper } \\
\text { Universal, } \\
\text { WaveOne } \\
\text { and TFA }\end{array}$ & Yes & SEM & No & Yes \\
\hline
\end{tabular}


Table 4. Cont

\begin{tabular}{|c|c|c|c|c|c|c|c|c|c|c|c|c|c|c|c|}
\hline No. & Title & Authors & Journal & Country & Year & Teeth & No. of Samples & $\begin{array}{c}\text { Pre Instrumen- } \\
\text { tation } \\
\text { Evaluation for } \\
\text { Cracks }\end{array}$ & Root Curvature & Control Group & File Group & $\begin{array}{c}\text { Sectioning } 3 \\
\mathrm{~mm}, 6 \mathrm{~mm}, 9 \\
\mathrm{~mm}\end{array}$ & $\begin{array}{l}\text { Examination } \\
\text { Method }\end{array}$ & $\begin{array}{l}\text { Methodology Is } \\
\text { Well Described }\end{array}$ & Irrigant \\
\hline 11. & $\begin{array}{l}\text { Effect of Reciprocating File } \\
\text { Motion on Microcrack } \\
\text { Formation in Root Canals: an } \\
\text { SEM Study [422]. }\end{array}$ & $\begin{array}{l}\text { Ashwinkumar, Krithikadatta, } \\
\text { Surendran, and Velmurugan }\end{array}$ & PubMed & India & 2013 & $\begin{array}{c}\text { Mandibular } 1^{\text {st }} \\
\text { molars }\end{array}$ & 150 & Yes & $\begin{array}{l}\text { Curvature } \\
\left(25-30^{\circ}\right)\end{array}$ & Unprepared & $\begin{array}{l}\text { ProTaper } \\
\text { Universal and } \\
\text { WaveOne }\end{array}$ & Yes & SEM & Yes & Yes \\
\hline 12. & $\begin{array}{l}\text { Incidence of Dentinal Cracks } \\
\text { after Root Canal } \\
\text { Preparation with ProTaper } \\
\text { Gold, Profili Vortex } \\
\text { F360, Reciproc and ProTaper } \\
\text { [43]. }\end{array}$ & $\begin{array}{l}\text { Karatas, Gunduz, Kircl, and } \\
\text { Arslan }\end{array}$ & PubMed & Turkey & 2016 & $\begin{array}{c}\text { Mandibular central } \\
\text { incisors }\end{array}$ & 90 & Yes & Straight $\left(<5^{\circ}\right)$ & Unprepared & $\begin{array}{l}\text { ProTaper } \\
\text { Universal and } \\
\text { WaveOne }\end{array}$ & Yes & Stereomicroscope & Yes & Yes \\
\hline 13. & 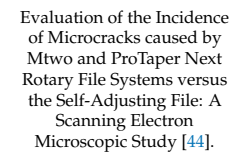 & 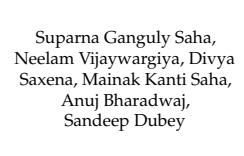 & PubMed & India & 2017 & $\begin{array}{c}\text { Mandibular } \\
\text { premolars }\end{array}$ & 120 & Yes & Straight canal & Unprepared & $\begin{array}{c}\text { ProTaper } \\
\text { Next, Mtwo and } \\
\text { SAF }\end{array}$ & Yes & Stereomicroscope & Yes & Yes \\
\hline
\end{tabular}




\section{Discussion}

The main aim of endodontic therapy is to clean and fill the RCS in order to preserve or regain the integrity of the periapical tissues [45]. Despite continuous developments in instruments to improve RCS cleaning [46], dentin microcracks continue to be a source of concern for clinicians and researchers $[47,48]$ as they often contribute to the instrumented tooth fracturing and extraction [49-51]. Although, there are multiple factors that contribute to dentinal crack formation like the design of the file, flexibility of file, and stress on the tooth surface used during instrumentation.

Files considered in the study are ProTaper Universal file and Mtwo which belong to the conventional NiTi file system group. The cross-sectional design of ProTaper Universal resembles that of a reamer, with three machined cutting edges and convex core [52]. The Mtwo files cross-sectional design resembles that of the S-file [53]. It has no radial lands, progressive blade pitch from tip to shaft, positive rake angles, and a non-cutting tip. Mtwo files have two cutting edges with minimal radial contact providing maximum space for dentin removal. It is advised by the manufacture to use all files in the instrumentation sequence to the full length of the root canal [54]. ProTaper Next is fabricated utilizing M-wire technology which helps to increase file flexibility. The off-centered rectangular cross section and the unique design of the file generate enlarged space for debris [55]. WaveOne made of M-wire metallurgy have a reverse helix and 2 distinct cross-sections along the length of their active portions. From D1-D8, the WaveOne files have a modified convex triangular cross-section, whereas from D9-D16, these files have a convex triangular cross-section [56]. Reciproc also made of M-wire technology consist of s-shaped cross section, the variable taper, the cutting angles and the thermally improved raw material provides high efficiency and cutting performance. The file's tip is non-cutting for a gentle treatment near the apex [57]. Twisted File Adaptive (TFA) is made up of R-phase heat treatment, twisting of the metal wire, and a special surface conditioning [58]. As a result of this it is consider superior to traditional NiTi instruments respect to their flexibility; cyclic fatigue resistance, cutting efficiency, and their ability maintain the original canal shape with minimal transportation $[59,60]$. K3XF consists of modified triple and developed by R-phase heat treatment [61]. Self-adjusting files system (SAF) file system is a hollow-file system that adapts to wall of the root canal according to anatomy of the canal [62]. Although there are different design and cross sections of the files developed there is still development on dentinal cracks during root canal instrumentation.

Another important factor that contributes to dentinal cracks is improper tooth preparation. It is often seen that rough dehydration leads to fracturing, cracking and volumetric shrinkage [63]. It recommended to prepare the tooth with lubricants to replace water before root canal instrumentation for desired results to avoids necessary factors affecting the desired results [64]. Although the step of tooth preparation is an important step in root canal instrumentation it is described in detail in the studies included in the systematic review.

The aim of this systematic analysis was to assess the prevalence of dentin microcracks after using instruments made with conventional, R-Phase, and M-Wire NiTi alloys and the SAF system. A systematic review of the literature is a coordinated review focused on a pre-established approach to classify, pick, and critically examine important studies regarding a topic or doubt. The aim of systematization is to reduce the significant amounts of prejudices that are typically present in a traditional or non-systematic analysis of the literature [65]. Critically, studies that involved the use of mandibular teeth with a maximum curvature of 40 degrees and no prior dentinal microcracks were included. The studies also processed a control group and comparative classes that were used in the review. As a result, the frequency of microcracks could be determined using a SEM and a stereomicroscope, which examined cross-sections at $3 \mathrm{~mm}, 6 \mathrm{~mm}$, and $9 \mathrm{~mm}$ from the apex.

In this systematic analysis, 1529 teeth samples were studied, with mandibular premolars and central incisors being the most commonly used teeth. Three research $[33,39,42]$ recorded teeth with root curvature, while others reported teeth with a straight root. The 
curvature specifics were not defined by Zhou et al [41]. Conventional NiTi file systems were the most commonly used, followed by M-wire file systems. All experiments that used traditional NiTi files as an experimental group used the ProTaper Universal method. WaveOne method was used in 7 studies for M-wire, with ProTaper Next and Reciproc following it. R-TFA phase's system was the most widely used.

When the occurrence of dentinal microcracks at various cross-sections was examined using SEM after using traditional NiTi file systems, a greater number of defects were found after using the ProTaper Universal method [32,34,36-38,41,43,44]. WaveOne was associated with the highest number of dentinal defects among M-wire systems [33,34,36,42]. Four M-wire studies $[32,38,40,42]$ that used ProTaper Next have registered a rise in the number of dentinal cracks scanned. There were less dentinal microcracks after using R-phase and SAF (hollow-file system). Moreover, it should be noted that R-phase and SAF instruments were the least often included in the studies included in this systematic analysis. Kansal et al., in 2014, Saha et al., in 2017, and Kumari and Vishwas, in 2016, did not disclose any data at 6 and $9 \mathrm{~mm}$ cross-sections, so their conclusions might be inadequate. Zhou et al., in 2015, used all three mechanisms and found the lowest number of dentinal cracks as compared to the other findings in the study. The highest number of dentinal cracks was observed at $3 \mathrm{~mm}$ from the root apex, although as the distance from the apex increases, the number of microcracks decreases, with the least recorded at the $9 \mathrm{~mm}$ cross-section. See Table 5 for more information. 
Table 5. Joanna Briggs' quality assessment criteria.

\begin{tabular}{|c|c|c|c|c|c|c|c|c|c|c|c|c|c|c|}
\hline No. & & $\begin{array}{l}\text { Akshayraj } \\
\text { K et al., } \\
2018\end{array}$ & $\begin{array}{l}\text { Yazdan } \\
\text { Shantiaee } \\
\text { et al., } 2018\end{array}$ & $\begin{array}{l}\text { Bürklein } \\
\text { S et al., } \\
2012\end{array}$ & $\begin{array}{c}\text { Rohit } \\
\text { Kansal } \\
\text { et al., } 2015\end{array}$ & $\begin{array}{l}\text { Karataş } \\
\text { E et al., } \\
2014\end{array}$ & $\begin{array}{l}\text { Yakup } \\
\text { Ustun } \\
\text { et al., } 2019\end{array}$ & $\begin{array}{l}\text { Prashant } \\
\text { Monga } \\
\text { et al., } 2015\end{array}$ & $\begin{array}{c}\text { Bertan } \\
\text { Kesim } \\
\text { et al., } \\
2017\end{array}$ & $\begin{array}{l}\text { R Ambika } \\
\text { Kumari } \\
\text { et al., } 2014\end{array}$ & $\begin{array}{l}\text { Xin } \\
\text { Zhou } \\
\text { et al., } \\
2015\end{array}$ & $\begin{array}{l}\text { V. Ash- } \\
\text { winkumar } \\
\text { et al., } 2013\end{array}$ & $\begin{array}{c}\text { E. } \\
\text { Karatas } \\
\text { et al., } \\
2015\end{array}$ & $\begin{array}{c}\text { Suparna } \\
\text { Ganguly, } \\
\text { Saha et al. } \\
2017\end{array}$ \\
\hline 1 & $\begin{array}{l}\text { Is there congruity between } \\
\text { the stated philosophical } \\
\text { perspective and the } \\
\text { research methodology? }\end{array}$ & Yes & Yes & Yes & Yes & Yes & Yes & Yes & Yes & Yes & Yes & Yes & Yes & Yes \\
\hline 2 & $\begin{array}{c}\text { Is there congruity between } \\
\text { the research methodology } \\
\text { and research question or } \\
\text { objectives? }\end{array}$ & Yes & Yes & Yes & Yes & Yes & Yes & Yes & Yes & Yes & Yes & Yes & Yes & Yes \\
\hline 3 & $\begin{array}{l}\text { Is there congruity between } \\
\text { the research methodology } \\
\text { and the method used to } \\
\text { collect data? }\end{array}$ & Yes & Yes & Yes & Yes & Yes & Yes & Yes & Yes & Yes & Yes & Yes & Yes & Yes \\
\hline 4 & $\begin{array}{l}\text { Is there congruity between } \\
\text { the research methodology } \\
\text { and representation and } \\
\text { analysis of data? }\end{array}$ & Yes & Yes & Yes & Yes & Yes & Yes & Yes & Yes & Yes & Yes & Yes & Yes & Yes \\
\hline 5 & $\begin{array}{l}\text { Is there congruity between } \\
\text { the research methodology } \\
\text { and interpretation of } \\
\text { results? }\end{array}$ & Yes & Yes & Yes & Yes & Yes & Yes & Yes & Yes & Yes & Yes & Yes & Yes & Yes \\
\hline 6 & $\begin{array}{c}\text { Is there a statement locating } \\
\text { the researcher culturally or } \\
\text { theoretically? }\end{array}$ & No & No & No & No & No & No & No & No & No & No & No & No & No \\
\hline 7 & $\begin{array}{l}\text { Is the influence of } \\
\text { researchers on the research } \\
\text { and vice versa addressed? }\end{array}$ & No & No & No & No & No & No & No & No & No & No & No & No & No \\
\hline 8 & $\begin{array}{l}\text { Are the participants and } \\
\text { their voices adequately } \\
\text { represented? }\end{array}$ & $\begin{array}{l}\text { Not ap- } \\
\text { plicable }\end{array}$ & $\begin{array}{c}\text { Not } \\
\text { applicable }\end{array}$ & $\begin{array}{l}\text { Not ap- } \\
\text { plicable }\end{array}$ & $\begin{array}{c}\text { Not } \\
\text { applicable }\end{array}$ & $\begin{array}{l}\text { Not ap- } \\
\text { plicable }\end{array}$ & $\begin{array}{c}\text { Not } \\
\text { applicable }\end{array}$ & $\begin{array}{c}\text { Not } \\
\text { applicable }\end{array}$ & $\begin{array}{l}\text { Not ap- } \\
\text { plicable }\end{array}$ & $\begin{array}{c}\text { Not } \\
\text { applicable }\end{array}$ & $\begin{array}{l}\text { Not ap- } \\
\text { plicable }\end{array}$ & $\begin{array}{c}\text { Not } \\
\text { applicable }\end{array}$ & $\begin{array}{l}\text { Not ap- } \\
\text { plicable }\end{array}$ & $\begin{array}{c}\text { Not } \\
\text { applicable }\end{array}$ \\
\hline 9 & $\begin{array}{l}\text { Is the research ethical } \\
\text { according to the current } \\
\text { criteria for recent studies } \\
\text { and is there evidence of } \\
\text { ethical approval by an } \\
\text { appropriate body? }\end{array}$ & Yes & Yes & Yes & Yes & Yes & Yes & Yes & Yes & Yes & Yes & Yes & Yes & Yes \\
\hline 10 & $\begin{array}{l}\text { Are the conclusions drawn } \\
\text { in the project report flow } \\
\text { from the analysis or } \\
\text { interpretation of data? }\end{array}$ & Yes & Yes & Yes & Unclear & Yes & Yes & Yes & Yes & Unclear & Yes & Yes & Yes & Unclear \\
\hline
\end{tabular}


All of the experiments had a control group for reference and a well-described protocol that was reported and evaluated using the Joanna Briggs' quality evaluation of in vitro studies' criterion [31]. The papers were evaluated based on their congruence between the research methodology and the research topic or purpose, the process used to gather data, data representation and analysis, and interpretation of findings. Only papers that met these conditions were included (Table 6).

Table 6. Number of dentinal cracks in different cross-sections.

\begin{tabular}{|c|c|c|c|c|c|c|c|c|}
\hline \multirow[t]{2}{*}{ No. } & \multirow[t]{2}{*}{ Title } & \multirow[t]{2}{*}{ File System } & \multirow[t]{2}{*}{ Files Used } & \multirow[t]{2}{*}{$\begin{array}{c}\text { No. of } \\
\text { Specimen }\end{array}$} & \multicolumn{4}{|c|}{$\begin{array}{c}\text { Number of Dentinal Cracks at } \\
\text { Different Cross-Sections }\end{array}$} \\
\hline & & & & & $3 \mathrm{~mm}$ & $6 \mathrm{~mm}$ & $9 \mathrm{~mm}$ & Total \\
\hline \multirow{4}{*}{1.} & \multirow{4}{*}{$\begin{array}{l}\text { In Vitro Comparative Evaluation of } \\
\text { Dentinal Microcracks' Formation during } \\
\text { Root Canal Preparation by Different } \\
\text { Nickel-Titanium File Systems [32]. }\end{array}$} & $\begin{array}{l}\text { Conventional } \\
\text { NiTi file system }\end{array}$ & $\begin{array}{l}\text { ProTaper } \\
\text { Universal }\end{array}$ & 12 & 4 & 3 & 7 & 14 \\
\hline & & $\begin{array}{l}\text { Hollow-file } \\
\text { system }\end{array}$ & SAF & 12 & 0 & 0 & 0 & 0 \\
\hline & & M-wire & $\begin{array}{l}\text { ProTaper } \\
\text { Next }\end{array}$ & 12 & 2 & 2 & 4 & 8 \\
\hline & & & WaveOne & 12 & 1 & 1 & 3 & 5 \\
\hline \multirow[t]{2}{*}{2.} & \multirow{2}{*}{$\begin{array}{c}\text { Effect of Root Canal Preparation } \\
\text { Techniques on } \\
\text { Crack Formation in Root Dentin [33]. }\end{array}$} & $\begin{array}{l}\text { Conventional } \\
\text { NiTi file system }\end{array}$ & $\begin{array}{l}\text { ProTaper } \\
\text { Universal }\end{array}$ & 30 & 5 & 5 & 8 & 18 \\
\hline & & M-wire & WaveOne & 30 & 15 & 9 & 3 & 27 \\
\hline \multirow{4}{*}{3.} & \multirow{4}{*}{$\begin{array}{l}\text { Incidence of Dentinal Defects after Root } \\
\text { Canal Preparation Reciprocating versus } \\
\text { Rotary Instrumentation [34]. }\end{array}$} & \multirow[t]{2}{*}{$\begin{array}{l}\text { Conventional } \\
\text { NiTi file system }\end{array}$} & $\begin{array}{l}\text { ProTaper } \\
\text { Universal }\end{array}$ & 60 & 10 & 10 & 3 & 23 \\
\hline & & & Mtwo & 60 & 7 & 7 & 6 & 20 \\
\hline & & \multirow{2}{*}{ M-wire } & Reciproc & 60 & 21 & 15 & 4 & 40 \\
\hline & & & WaveOne & 60 & 17 & 13 & 4 & 34 \\
\hline \multirow[t]{2}{*}{4.} & \multirow{2}{*}{$\begin{array}{l}\text { Assessment of Dentinal Damage during } \\
\text { Canal Preparation Using Reciprocating } \\
\text { and Rotary Files [35]. }\end{array}$} & $\begin{array}{l}\text { Conventional } \\
\text { NiTi file system }\end{array}$ & $\begin{array}{l}\text { ProTaper } \\
\text { Universal }\end{array}$ & 30 & & & & 16 \\
\hline & & M-wire & WaveOne & 30 & & & & 5 \\
\hline \multirow{4}{*}{5.} & \multirow{4}{*}{$\begin{array}{l}\text { Dentinal Crack Formation during Root } \\
\text { Canal Preparations by the Twisted File } \\
\text { Adaptive, ProTaper Next, ProTaper } \\
\text { Universal and WaveOne Instruments [36]. }\end{array}$} & $\begin{array}{l}\text { Conventional } \\
\text { NiTi file system }\end{array}$ & $\begin{array}{l}\text { ProTaper } \\
\text { Universal }\end{array}$ & 15 & 6 & 5 & 6 & 17 \\
\hline & & M-wire & $\begin{array}{l}\text { ProTaper } \\
\text { Next }\end{array}$ & 15 & 1 & 6 & 4 & 11 \\
\hline & & & WaveOne & 15 & 6 & 4 & 5 & 15 \\
\hline & & R-phase & TFA & 15 & 1 & 5 & 7 & 13 \\
\hline \multirow{3}{*}{6.} & \multirow{3}{*}{$\begin{array}{c}\text { The Effects of Different Nickel-Titanium } \\
\text { Instruments on Dentinal microcrack } \\
\text { Formations during Root Canal } \\
\text { Preparation [37]. }\end{array}$} & $\begin{array}{l}\text { Conventional } \\
\text { NiTi file system }\end{array}$ & $\begin{array}{l}\text { ProTaper } \\
\text { Universal }\end{array}$ & 20 & 4 & 3 & 1 & 8 \\
\hline & & M-wire & $\begin{array}{l}\text { ProTaper } \\
\text { Next }\end{array}$ & 20 & 4 & 3 & 0 & 7 \\
\hline & & & Reciproc & 20 & 1 & 1 & 0 & 2 \\
\hline \multirow{3}{*}{7.} & \multirow{3}{*}{$\begin{array}{c}\text { Comparison of Incidence of Dentinal } \\
\text { Defects after Root Canal Preparation with } \\
\text { Continuous Rotation and Reciprocating } \\
\text { Instrumentation [38] }\end{array}$} & $\begin{array}{l}\text { Conventional } \\
\text { NiTi file system }\end{array}$ & $\begin{array}{l}\text { ProTaper } \\
\text { Universal }\end{array}$ & 30 & 0 & 3 & 2 & 5 \\
\hline & & R-phase & $\mathrm{K} 3 \mathrm{XF}$ & 30 & 2 & 0 & 0 & 2 \\
\hline & & M-wire & WaveOne & 30 & 0 & 1 & 0 & 1 \\
\hline \multirow{4}{*}{8.} & \multirow{4}{*}{$\begin{array}{c}\text { Evaluation of Dentinal Defects during } \\
\text { Root Canal Preparation Using } \\
\text { Thermomechanically- Processed } \\
\text { Nickel-Titanium Files [39]. }\end{array}$} & \multirow[t]{2}{*}{ M-wire } & $\begin{array}{l}\text { ProTaper } \\
\text { Next }\end{array}$ & 30 & 7 & 4 & 2 & 13 \\
\hline & & & Reciproc & 30 & 0 & 1 & 2 & 3 \\
\hline & & \multirow{2}{*}{ R-phase } & TFA & 30 & 6 & 4 & 6 & 16 \\
\hline & & & $\mathrm{K} 3 \mathrm{XF}$ & 30 & 0 & 1 & 2 & 3 \\
\hline \multirow{3}{*}{9.} & \multirow{3}{*}{$\begin{array}{l}\text { To Compare the Incidence of Dentinal } \\
\text { Cracks after Instrumentation with Rotary, } \\
\text { Reciprocating Twisted File Adaptive } \\
\text { System [40]. }\end{array}$} & M-wire & $\begin{array}{l}\text { ProTaper } \\
\text { Next }\end{array}$ & 10 & 4 & 5 & $\begin{array}{l}\text { No } \\
\text { data }\end{array}$ & \\
\hline & & & Reciproc & 10 & 2 & 2 & $\begin{array}{l}\text { No } \\
\text { data }\end{array}$ & \\
\hline & & R-phase & TFA & 10 & 2 & 1 & $\begin{array}{l}\text { No } \\
\text { data }\end{array}$ & \\
\hline
\end{tabular}


Table 6. Cont.

\begin{tabular}{|c|c|c|c|c|c|c|c|c|}
\hline \multirow[t]{2}{*}{ No. } & \multirow[t]{2}{*}{ Title } & \multirow[t]{2}{*}{ File System } & \multirow[t]{2}{*}{ Files Used } & \multirow[t]{2}{*}{$\begin{array}{c}\text { No. of } \\
\text { Specimen }\end{array}$} & \multicolumn{4}{|c|}{$\begin{array}{l}\text { Number of Dentinal Cracks at } \\
\text { Different Cross-Sections }\end{array}$} \\
\hline & & & & & $3 \mathrm{~mm}$ & $6 \mathrm{~mm}$ & $9 \mathrm{~mm}$ & Total \\
\hline \multirow{3}{*}{10.} & \multirow{3}{*}{$\begin{array}{l}\text { Comparison of Dentinal and Apical Crack } \\
\text { Formation caused by Four Different } \\
\text { Nickel-Titanium Rotary and Reciprocating } \\
\text { Systems in Large and Small Canals [41]. }\end{array}$} & $\begin{array}{l}\text { Conventional } \\
\text { NiTi file system }\end{array}$ & $\begin{array}{l}\text { ProTaper } \\
\text { Universal }\end{array}$ & 20 & 0 & 1 & 0 & 1 \\
\hline & & M-wire & WaveOne & 20 & 1 & 1 & 1 & 3 \\
\hline & & R-phase & TFA & 20 & 0 & 0 & 0 & 0 \\
\hline \multirow[t]{2}{*}{11} & \multirow{2}{*}{$\begin{array}{l}\text { Effect of Reciprocating File Motion on } \\
\text { Microcrack Formation in Root Canals: an } \\
\text { SEM Study [42]. }\end{array}$} & $\begin{array}{l}\text { Conventional } \\
\text { NiTi file system }\end{array}$ & $\begin{array}{l}\text { ProTaper } \\
\text { Universal }\end{array}$ & 30 & 22 & 24 & 26 & 72 \\
\hline & & M-wire & WaveOne & 30 & 9 & 12 & 14 & 35 \\
\hline \multirow[t]{2}{*}{12.} & \multirow{2}{*}{$\begin{array}{c}\text { Incidence of Dentinal Cracks after Root } \\
\text { Canal Preparation with ProTaper Gold, } \\
\text { Profile Vortex, F360, Reciproc and ProTape } \\
\text { Universal instruments [43]. }\end{array}$} & $\begin{array}{l}\text { Conventional } \\
\text { NiTi } \\
\text { file system } \\
\end{array}$ & $\begin{array}{l}\text { ProTaper } \\
\text { Universal }\end{array}$ & 15 & 4 & 4 & 2 & 10 \\
\hline & & M-wire & Reciproc & 15 & 0 & 1 & 4 & 5 \\
\hline \multirow{3}{*}{13.} & \multirow{3}{*}{$\begin{array}{l}\text { Evaluation of the Incidence of Microcracks } \\
\text { caused by Mtwo and ProTaper Next Rotary } \\
\text { File Systems versus the Self-Adjusting File: A } \\
\text { Scanning Electron Microscopic Study [44]. }\end{array}$} & $\begin{array}{l}\text { Conventional } \\
\text { NiTi file system }\end{array}$ & Mtwo & 30 & & & & 15 \\
\hline & & M-wire & $\begin{array}{l}\text { ProTaper } \\
\text { Next }\end{array}$ & 30 & & & & 12 \\
\hline & & $\begin{array}{l}\text { Hollow-file } \\
\text { system }\end{array}$ & SAF & 30 & & & & 1 \\
\hline
\end{tabular}

The development of emerging technology used in the manufacturing of endodontic instruments seems to reduce the occurrence of dentin microcracks. NiTi files generated using M-wire and R-phase technologies had a lower incidence of dentinal microcracks, especially in the apical third.

\section{Limitations}

The literature review was undertaken using major databases; however, articles that are published elsewhere may have been overlooked. As a result, the papers used in the present systematic review were written in English, and some important evidence may have been overlooked as several papers may have been published in other languages. Only a few studies yielded inconclusive findings. The lack of standardization of cross-section length from the root apex resulted in varying cross-section lengths. The existence of selective research performed using new generation file systems was the main drawback of this systematic analysis.

\section{Conclusions}

Despite the shortcomings of this systematic review, it is possible to infer that the use of endodontic NiTi files manufactured using M-wire and R-phase technology provides a better biomechanical preparation by preventing the development of dentinal microcracks. The conclusion of the systematic review is drawn based on the limited number of publications.

Author Contributions: Conceptualization, K.S., A.M.P., and M.I.K.; methodology, K.S., K.S.B., and R.M.; validation, R.M., A.M. and P.M.; formal analysis, A.M.P., M.I.K., G.A.S.; data curation, K.S., A.M.P. and K.S.B.; writing—original draft preparation, K.S., and M.I.K.; writing—review and editing, A.M.P., A.M., and G.A.S.; supervision, A.M.P. and G.A.S.; project administration, A.M.P. and M.I.K.; funding acquisition, P.M. and G.A.S. All authors have read and agreed to the published version of the manuscript.

Funding: This research received no external funding.

Data Availability Statement: The data used to support the findings of this study are available from the corresponding authors upon request.

Conflicts of Interest: The authors declare no conflict of interest. 


\section{References}

1. Tabassum, S.; Khan, F.R. Failure of endodontic treatment: The usual suspects. Eur. J. Dent. 2016, 10, 144-147. [CrossRef]

2. Del Fabbro, M.; Corbella, S.; Sequeira-Byron, P.; Tsesis, I.; Rosen, E.; Lolato, A.; Taschieri, S. Endodontic procedures for retreatment of periapical lesions. Cochrane Database Syst. Rev. 2016, 10, CD005511. [CrossRef]

3. Hargreaves, K.M.; Berman, L.H. Cohen's Pathways of the Pulp Expert Consult; Elsevier Health Sciences: Amsterdam, The Netherlands, 2015.

4. Estrela, C.; Bueno, M.R.; Leles, C.R.; Azevedo, B.; Azevedo, J.R. Accuracy of cone beam computed tomography and panoramic and periapical radiography for detection of apical periodontitis. J. Endod. 2008, 34, 273-279. [CrossRef]

5. Siqueira, J.F.; Rôças, I.N. Clinical implications and microbiology of bacterial persistence after treatment procedures. J. Endod. 2008, 34, 1291-1301.e3. [CrossRef]

6. Soares, C.J.; Rodrigues, M.D.; Faria-e-Silva, A.L.; Santos-Filho, P.C.; Veríssimo, C.; Kim, H.C.; Versluis, A. How biomechanics can affect the endodontic treated teeth and their restorative procedures? Braz. Oral Res. 2018, 32, e76. [CrossRef]

7. Stewart, G.G. The importance of chemomechanical preparation of the root canal. Oral Surg. Oral Med. Oral Pathol. 1955, 8 , 993-997. [CrossRef]

8. Schilder, H. Cleaning and shaping the root canal. Dent. Clin. N. Am. 1974, 18, 269-296.

9. Marais, J.T. The evolution of modern non-iatrogenic root canal preparation techniques. J. Dent. Assoc. S. Afr. 1996, 51, 587-592. [PubMed]

10. Baumann, M.A. Nickel-titanium: Options and challenges. Dent. Clin. N. Am. 2004, 48, 55-67. [CrossRef] [PubMed]

11. Bryant, S.T.; Dummer, P.M.; Pitoni, C.; Bourba, M.; Moghal, S. Shaping ability of 0.04 and 0.06 taper ProFile rotary nickel-titanium instruments in simulated root canals. Int. Endod. J. 1999, 32, 155-164. [CrossRef]

12. Hata, G.; Uemura, M.; Kato, A.S.; Imura, N.; Novo, N.F.; Toda, T. A comparison of shaping ability using ProFile, GT file, and Flex-R endodontic instruments in simulated canals. J. Endod. 2002, 28, 316-321. [CrossRef]

13. Yun, H.H.; Kim, S.K. A comparison of the shaping abilities of 4 nickel-titanium rotary instruments in simulated root canals. Oral Surg. Oral Med. Oral Pathol. Oral Radiol. Endod. 2003, 95, 228-233. [CrossRef] [PubMed]

14. Zupanc, J.; Vahdat-Pajouh, N.; Schafer, E. New thermomechanically treated NiTi alloys-A review. Int. Endod. J. 2018, 51, 1088-1103. [CrossRef] [PubMed]

15. Gambarini, G.; Grande, N.M.; Plotino, G.; Somma, F.; Garala, M.; De Luca, M.; Testarelli, L. Fatigue resistance of engine-driven rotary nickel-titanium instruments produced by new manufacturing methods. J. Endod. 2008, 34, 1003-1005. [CrossRef]

16. Berendt, C. Method of Preparing Nitinol for Use in Manufacturing Instruments with Improved Fatigue Resistance. U.S. Patent US20070072147A1, 19 January 2007.

17. Montalvao, D.; Alcada, F.S. Numeric comparison of the static mechanical behavior between ProFile GT and ProFile GT series X rotary nickel-titanium files. J. Endod. 2011, 37, 1158-1161. [CrossRef] [PubMed]

18. Gao, Y.; Gutmann, J.L.; Wilkinson, K.; Maxwell, R.; Ammon, D. Evaluation of the impact of raw materials on the fatigue and mechanical properties of ProFile Vortex rotary instruments. J. Endod. 2012, 38, 398-401. [CrossRef] [PubMed]

19. Pereira, E.S.; Gomes, R.O.; Leroy, A.M.; Singh, R.; Peters, O.A.; Bahia, M.G.; Buono, V. Mechanical behavior of M-Wire and conventional NiTi wire used to manufacture rotary endodontic instruments. Dent. Mater. 2013, 29, e318-e324. [CrossRef]

20. Larsen, C.M.; Watanabe, I.; Glickman, G.N.; He, J. Cyclic fatigue analysis of a new generation of nickel titanium rotary instruments. J. Endod. 2009, 35, 401-403. [CrossRef] [PubMed]

21. Wu, S.K.L.; Lin, H.C.; Chou, T.S. A study of electrical resistivity, internal friction and shear modulus on an aged Ti49Ni51 alloy. Acta Metall. Mater. 1990, 38, 95-102. [CrossRef]

22. Hou, X.; Yahata, Y.; Hayashi, Y.; Ebihara, A.; Hanawa, T.; Suda, H. Phase transformation behaviour and bending property of twisted nickel-titanium endodontic instruments. Int. Endod. J. 2011, 44, 253-258. [CrossRef]

23. Metzger, Z.; Teperovich, E.; Zary, R.; Cohen, R.; Hof, R. The self-adjusting file (SAF). Part 1: Respecting the root canal anatomy-a new concept of endodontic files and its implementation. J. Endod. 2010, 36, 679-690. [CrossRef]

24. Metzger, Z.; Teperovich, E.; Cohen, R.; Zary, R.; Paque, F.; Hulsmann, M. The self-adjusting file (SAF). Part 3: Removal of debris and smear layer-A scanning electron microscope study. J. Endod. 2010, 36, 697-702. [CrossRef]

25. De Alencar, A.H.; Dummer, P.M.; Oliveira, H.C.; Pecora, J.D.; Estrela, C. Procedural errors during root canal preparation using rotary NiTi instruments detected by periapical radiography and cone beam computed tomography. Braz. Dent. J. 2010, 21, 543-549. [CrossRef]

26. Guedes, O.A.; Da Costa, M.V.C.; Dorilêo, M.C.G.O.; De Oliveira, H.F.; Pedro, F.L.M.; Bandeca, M.C.; Borges Álvaro, H. Detection of Procedural Errors during Root Canal Instrumentation using Cone Beam Computed Tomography. J. Int. Oral Health 2015, 7, 28-32.

27. Priya, N.T.; Chandrasekhar, V.; Anita, S.; Tummala, M.; Raj, T.B.; Badami, V.; Kumar, P.; Soujanya, E. “Dentinal microcracks after root canal preparation" a comparative evaluation with hand, rotary and reciprocating instrumentation. J. Clin. Diagn. Res. 2014, 8, ZC70-ZC72. [CrossRef]

28. Toure, B.; Faye, B.; Kane, A.W.; Lo, C.M.; Niang, B.; Boucher, Y. Analysis of reasons for extraction of endodontically treated teeth: A prospective study. J. Endod. 2011, 37, 1512-1515. [CrossRef]

29. Udoye, C.I.; Jafarzadeh, H.; Kinoshita, J.I.; Manabe, A.; Kobayashi, M. Prevalence and Reasons for Extraction of Endodontically Treated Teeth in Adult Nigerians. J. Contemp. Dent. Pract. 2018, 19, 1469-1473. [CrossRef] [PubMed] 
30. Chrysanthakopoulos, N.A. Reasons for extraction of permanent teeth in Greece: A five-year follow-up study. Int. Dent. J. 2011, 61, 19-24. [CrossRef] [PubMed]

31. Joanna Briggs Institute. Joanna Briggs Institute Reviewers' Manual; The Systematic Review of Economic Evaluation Evidence; Joanna Briggs Institute: Adelaide, Australia, 2014.

32. Langaliya, A.K.; Kothari, A.K.; Surti, N.R.; Patel, A.R.; Doshi, P.R.; Pandya, D.J. In vitro comparative evaluation of dentinal microcracks formation during root canal preparation by different nickel-titanium file systems. Saudi Endod. J. 2018, 8, 183-188.

33. Shantiaee, Y.; Dianat, O.; Mosayebi, G.; Namdari, M.; Tordik, P. Effect of Root Canal Preparation Techniques on Crack Formation in Root Dentin. J. Endod. 2019, 45, 447-452. [CrossRef]

34. Burklein, S.; Tsotsis, P.; Schafer, E. Incidence of dentinal defects after root canal preparation: Reciprocating versus rotary instrumentation. J. Endod. 2013, 39, 501-504. [CrossRef]

35. Kansal, R.; Rajput, A.; Talwar, S.; Roongta, R.; Verma, M. Assessment of dentinal damage during canal preparation using reciprocating and rotary files. J. Endod. 2014, 40, 1443-1446. [CrossRef]

36. Karatas, E.; Gunduz, H.A.; Kirici, D.O.; Arslan, H.; Topcu, M.C.; Yeter, K.Y. Dentinal crack formation during root canal preparations by the twisted file adaptive, ProTaper Next, ProTaper Universal, and WaveOne instruments. J. Endod. 2015, 41, 261-264. [CrossRef] [PubMed]

37. Ustun, Y.; Aslan, T.; Sagsen, B.; Kesim, B. The effects of different nickel-titanium instruments on dentinal microcrack formations during root canal preparation. Eur. J. Dent. 2015, 9, 41-46. [CrossRef] [PubMed]

38. Monga, P.; Bajaj, N.; Mahajan, P.; Garg, S. Comparison of incidence of dentinal defects after root canal preparation with continuous rotation and reciprocating instrumentation. Singap. Dent. J. 2015, 36, 29-33. [CrossRef]

39. Kesim, B.; Sagsen, B.; Aslan, T. Evaluation of dentinal defects during root canal preparation using thermomechanically processed nickel-titanium files. Eur. J. Dent. 2017, 11, 157-161. [CrossRef] [PubMed]

40. Kumari, R.A.; Vishwas, M.S. To compare the Incidence of Dentinal Cracks after Instrumentation with Rotary, Reciprocating Twisted File Adaptive System. CODS J. Dent. 2016, 8, 100-103. [CrossRef]

41. Zhou, X.; Jiang, S.; Wang, X.; Wang, S.; Zhu, X.; Zhang, C. Comparison of dentinal and apical crack formation caused by four different nickel-titanium rotary and reciprocating systems in large and small canal. Dent. Mater. J. 2015, 34, 903-909. [CrossRef]

42. Ashwinkumar, V.; Krithikadatta, J.; Surendran, S.; Velmurugan, N. Effect of reciprocating file motion on microcrack formation in root canals: An SEM study. Int. Endod. J. 2014, 47, 622-627. [CrossRef]

43. Karatas, E.; Gunduz, H.A.; Kirici, D.O.; Arslan, H. Incidence of dentinal cracks after root canal preparation with ProTaper Gold, Profile Vortex, F360, Reciproc and ProTaper Universal instruments. Int. Endod. J. 2016, 49, 905-910. [CrossRef]

44. Saha, S.G.; Vijaywargiya, N.; Saxena, D.; Saha, M.K.; Bharadwaj, A.; Dubey, S. Evaluation of the incidence of microcracks caused by Mtwo and ProTaper Next rotary file systems versus the self-adjusting file: A scanning electron microscopic study. J. Conserv. Dent. 2017, 20, 355-359. [CrossRef]

45. Holland, R.; Gomes Filho, J.E.; Cintra, L.T.; Queiroz, Í.O.; Estrela, C. Factors affecting the periapical healing process of endodontically treated teeth. J. Appl. Oral Sci. 2017, 25, 465-476. [CrossRef]

46. Ounsi, H.F.; Nassif, W.; Grandini, S.; Salameh, Z.; Neelakantan, P.; Anil, S. Evolution of Nickel-titanium Alloys in Endodontics. J. Contemp. Dent. Pract. 2017, 18, 1090-1096.

47. Cakici, F.; Cakici, E.B.; Sadik, B.; Keles, A.; Fundaoglu Kucukekenci, F. Comparison of newly formed microcracks after instrumentation using protaper next, reciproc and self-adjusting file systems. Eur. Oral Res. 2019, 53, 21-24. [CrossRef]

48. Capar, I.D.; Gok, T.; Uysal, B.; Keles, A. Comparison of microcomputed tomography, cone beam tomography, stereomicroscopy, and scanning electron microscopy techniques for detection of microcracks on root dentin and effect of different apical sizes on microcrack formation. Microsc. Res. Tech. 2019, 82, 1748-1755. [CrossRef]

49. Zadik, Y.; Sandler, V.; Bechor, R.; Salehrabi, R. Analysis of factors related to extraction of endodontically treated teeth. Oral Surg. Oral Med. Oral Pathol. Oral Radiol. Endodontol. 2008, 106, e31-e35. [CrossRef]

50. Olcay, K.; Ataoglu, H.; Belli, S. Evaluation of related factors in the failure of endodontically treated teeth: A cross-sectional study. J. Endod. 2018, 44, 38-45. [CrossRef]

51. Kojima, K.; Inamoto, K.; Nagamatsu, K.; Hara, A.; Nakata, K.; Morita, I.; Nakagaki, H.; Nakamura, H. Success rate of endodontic treatment of teeth with vital and nonvital pulps. A meta-analysis. Oral Surg. Oral Med. Oral Pathol. Oral Radiol. Endodontol. 2004, 97, 95-99. [CrossRef]

52. Gambarini, G.; Laszkiewicz, J. A scanning electron microscopic study of debris and smear layer remaining following use of GT rotary instruments. Int. Endod. J. 2002, 35, 422-427. [CrossRef]

53. Foschi, F.; Nucci, C.; Montebugnoli, L.; Marchionni, S.; Breschi, L.; Malagnino, V.A.; Prati, C. SEM evaluation of canal wall dentine following use of Mtwo and ProTaper NiTi rotary instruments. Int. Endod. J. 2004, 37, 832-839. [CrossRef]

54. Schäfer, E.; Vlassis, M. Comparative investigation of two rotary nickel-titanium instruments: ProTaper versus RaCe. Part 2. Cleaning effectiveness and shaping ability in severely curved root canals of extracted teeth. Int. Endod. J. 2004, 37, 239-248. [CrossRef]

55. Uygun, A.D.; Kol, E.; Topcu, M.K.; Seckin, F.; Ersoy, I.; Tanriver, M. Variations in cyclic fatigue resistance among ProTaper Gold, ProTaper Next and ProTaper Universal instruments at different levels. Int. Endod. J. 2016, 49, 494-499. [CrossRef]

56. Plotino, G.; Giansiracusa Rubini, A.; Grande, N.M.; Testarelli, L.; Gambarini, G. Cutting efficiency of Reciproc and waveOne reciprocating instruments. J. Endod. 2014, 40, 1228-1230. [CrossRef] [PubMed] 
57. De Siqueira Zuolo, A.; Zuolo, M.L.; da Silveira Bueno, C.E.; Chu, R.; Cunha, R.S. Evaluation of the Efficacy of TRUShape and Reciproc File Systems in the Removal of Root Filling Material: An Ex Vivo Micro-Computed Tomographic Study. J. Endod. 2016, 42, 315-319. [CrossRef] [PubMed]

58. Kim, H.C.; Yum, J.; Hur, B.; Cheung, G.S. Cyclic fatigue and fracture characteristics of ground and twisted nickel-titanium rotary files. J. Endod. 2010, 36, 147-152. [CrossRef]

59. Yılmaz, K.; Özyürek, T. Apically extruded debris after retreatment procedure with Reciproc, ProTaper Next, and Twisted File Adaptive instruments. J. Endod. 2017, 43, 648-651. [CrossRef] [PubMed]

60. Gergi, R.; Rjeily, J.A.; Sader, J.; Naaman, A. Comparison of canal transportation and centering ability of twisted files, PathfileProTaper system, and stainless steel hand K-files by using computed tomography. J. Endod. 2010, 36, 904-907. [CrossRef] [PubMed]

61. Topçuoğlu, H.S.; Zan, R.; Akpek, F.; Topçuoğlu, G.; Ulusan, Ö.; Aktı, A.; Düzgün, S.; Ağırnasligil, M. Apically extruded debris during root canal preparation using Vortex Blue, K3XF, ProTaper Next and Reciproc instruments. Int. Endod. J. 2016, 49, 1183-1187. [CrossRef] [PubMed]

62. Hof, R.; Perevalov, V.; Eltanani, M.; Zary, R.; Metzger, Z. The self-adjusting file (SAF). Part 2: Mechanical analysis. J. Endod. 2010, 36, 691-696. [CrossRef]

63. Janda, R. Preparation of extracted natural human teeth for SEM investigations. Biomaterials 1995, 16, 209-217. [CrossRef]

64. Reimer, L.; Pfefferkorn, G. Raster-Elektronenmikroskopie; Springer: New York, NY, USA, 2013.

65. Halligan, S. Systematic reviews and meta-analysis of diagnostic tests. Clin. Radiol. 2005, 60, 977-979. [CrossRef] [PubMed] 